\title{
Erratum to: A spectrum of intracranial vascular high-flow arteriovenous shunts in RASA1 mutations
}

\author{
Pernilla Grillner $^{1}$ • Michael Söderman ${ }^{2,3} \cdot$ Staffan Holmin $^{2,3} \cdot$ Georges Rodesch $^{4}$
}

Published online: 9 November 2015

(C) Springer-Verlag Berlin Heidelberg 2015

\section{Erratum to: Childs Nerv Syst}

DOI 10.1007/s00381-015-2940-y

Unfortunately, one of the authors' name was misspelled in the original publication of this article. Instead of Micheal Söderman, it should have been Michael Söderman.

The online version of the original article can be found at http://dx.doi.org/ 10.1007/s00381-015-2940-y.

\footnotetext{
Pernilla Grillner

pernilla.grillner@ki.se

Michael Söderman

michael.soderman@karolinska.se

Staffan Holmin

staffan.holmin@ki.se

Georges Rodesch

g.rodesch@hopital-foch.org

1 Department of Neuropediatrics, Astrid Lindgren Children's Hospital, Karolinska University Hospital, Stockholm 171 76, Sweden

2 Department of Clinical Neuroscience, Karolinska Institutet, Stockholm, Sweden

3 Department of Neuroradiology, Karolinska University Hospital, Stockholm, Sweden

4 Service de Neuroradiologie Diagnostique et Thérapeutique, Hôpital Foch, Suresnes, France
} 